\title{
TRANS-SYNAPTIC MODULATION VIA MUSCARINIC RECEPTORS OF SEROTONIN-CONTAINING SMALL INTENSELY FLUORESCENT CELLS OF SUPERIOR CERVICAL GANGLION ${ }^{1}$
}

\author{
M. HADJICONSTANTINOU, P. E. POTTER, AND N. H. NEFF ${ }^{2}$ \\ Laboratory of Preclinical Pharmacology, National Institute of Mental Health, Saint Elizabeth's Hospital, \\ Washington, DC 20032
}

Received April 8, 1982; Revised June 14, 1982; Accepted June 16, 1982

\begin{abstract}
Verhofstad et al. (Verhofstad, A. A. J., H. W. M. Steinbusch, B. Penke, J. Varga, and H. W. J. Joosten (1981) Brain Res. 212: 39-49) have reported that serotonin of the rat superior cervical ganglion is contained in a distinct and separate population of small intensely fluorescent (SIF) cells. We provide evidence that the serotonin-containing SIF cells are modulated, in part, by preganglionic cholinergic neurons. For example, administration of the muscarinic agonists carbachol or oxotremorine increases the content of serotonin, and the increase induced by oxotremorine is blocked by atropine. Treatment with atropine alone or decentralization of the ganglion lowers the content of serotonin. From the rate of accumulation of serotonin in the ganglion after the administration of the monoamine oxidase inhibitor pargyline, it appears that the rate of formation of serotonin is increased after oxotremorine treatment. Reserpine, $\boldsymbol{p}$-chlorophenylalanine, or fluoxetine treatment reduces the content of serotonin in the ganglion, suggesting that the SIF cell system has properties similar to those of serotonergic neurons of the brain. We postulate that the serotonin-containing SIF cells of the rat superior cervical ganglion participate in local circuit modulation of ganglionic transmission by receiving preganglionic information via muscarinic receptors.
\end{abstract}

Recently, Verhofstad et al. (1981) demonstrated that the superior cervical ganglion of the rat contains separate serotonin- and catecholamine-containing small intensely fluorescent (SIF) cells. The serotonin-containing SIF cells were identified by their affinity for antiserum directed against serotonin. These SIF cells are located primarily at the poles of the ganglion near blood vessels, and they possess processes with varicosities. Only a few serotonin-immunoreactive mast cells are found within the ganglion. These observations are consistent with past reports of positive identification of serotonin in the superior cervical ganglion by gas chromatography-mass spectrometry (Liuzzi et al., 1977), of the presence of tryptophan hydroxylase in the ganglion (Liuzzi et al., 1977), and of modification of ganglionic transmission by serotonin (Hertzler, 1961; Wallis and Woodward, 1974; North et al., 1980; Dun and Karczmar, 1981). As dopamine metabolism in SIF cells appears to be modulated by preganglionic cholinergic neurons acting on muscarinic receptors (Libet and Owman, 1974; Karoum et al., 1977), we investigated the modulation of serotonin-con-

\footnotetext{
'We wish to thank Mr. Jeffrey Rubenstein for his expert technical assistance

"' ''o whom correspondence should be addressed.
}

taining SIF cells. We provide evidence that serotonincontaining SIF cells probably are modulated by preganglionic cholinergic nerves acting on muscarinic receptors as well. Indeed, preganglionic cholinergic neurons may end on the muscarinic receptors for local circuit regulation of ganglionic transmission and on the nicotinic receptors for passage of information to peripheral tissues.

\section{Materials and Methods}

Male Sprague-Dawley rats, 180 to $200 \mathrm{gm}$ (Zivic-Miller Laboratory, Allison Park, PA), were decapitated, and superior cervical ganglia were removed, cleaned of adhering tissue, and frozen for subsequent analysis of 5hydroxytryptophan (5-HTP), serotonin, 5-hydroxyindoleacetic acid (5-HIAA), and 3,4-dihydroxyphenylacetic acid (DOPAC). Unilateral superior cervical ganglion decentralization was performed by Zivic-Miller Laboratory. These animals were used 10 days after surgery. The contralateral ganglion has been referred to as sham surgery.

Sample analysis was performed by a modification of the high performance liquid chromatography with electrochemical detection (HPLC-ECD) method of Lackovic et al. (1981). Ganglia from one animal or a single ganglion from a surgically treated animal were homogenized with 
$\mathrm{ZnSO}_{4}(10 \%, \mathrm{w} / \mathrm{v})$ containing ascorbic acid $(0.02 \%, \mathrm{w} / \mathrm{v}$, $100 \mu \mathrm{l})$. Protein was precipitated by adding $\mathrm{NaOH}(0.5 \mathrm{~N}$, $75 \mu \mathrm{l}$ ). Samples were centrifuged at $28,000 \times \mathrm{g}$ for $10 \mathrm{~min}$. The supernatant (20 to $50 \mu \mathrm{l}$ ) was injected directly into the HPLC system.

The HPLC-ECD system consisted of a Bio-Sil ODSS10 15-cm column (Bio-Rad, Richmond, CA), with a mobile phase of citric acid $(0.1 \mathrm{M})$ adjusted with dibasic sodium phosphate $(0.2 \mathrm{M})$ to $\mathrm{pH} 3.5$ and diluted $1: 1$ with water, filtered, and degassed and to which methanol (8\%, $\mathrm{v} / \mathrm{v}$ ) was added. 'The flow rate was $1 \mathrm{ml} / \mathrm{min}$. The electrochemical detector (Bioanalytical Systems, Inc., West Lafayette, IN) was set to a potential of $0.50 \mathrm{~V}$. The retention times (in minutes) for 5-HTP, serotonin, 5HIAA, and DOPAC were $4.25,6.25,8.25$, and 15 , respectively. The ganglionic content of endogenous substances was calculated from standard curves. The doses of drugs administered and the times of killings are reported under "Results." Protein was determined by the procedure of Lowry et al. (1951).

\section{Results}

The steady state content of serotonin, 5-HIAA, and DOPAC in the rat superior cervical ganglion is shown in Table I. Our initial studies were designed to investigate whether there is an acid transport system for 5-HIAA in the ganglion as there is for DOPAC (Karoum et al., 1977). Although there was a significant rise of DOPAC 30 and $60 \mathrm{~min}$ after probenecid administration, there was no increase in the content of 5-HIAA in the ganglia (Table I). Higher doses of probenecid $(600 \mathrm{mg} / \mathrm{kg})$ could not be used because this resulted in the death of some of the rats. The lack of effect of probenecid suggests that, unlike DOPAC, 5-HIAA is not removed from the ganglion by a transport system. A possible mechanism for the loss of 5 HIAA from the ganglion could be diffusion into the circulation. In subsequent studies, we measured the content of serotonin in the ganglion as an indicator of the responsiveness of the serotonin-containing SIF cell system to various procedures.

The content of serotonin in the ganglion was influenced by cholinergic drugs (Table II). For example, muscarinic receptor agonists (oxotremorine or carbachol) increased the content of serotonin. In contrast, atropine treatment lowered serotonin or prevented the rise induced by oxotremorine. Nicotine or hexamethonium had no significant effect on serotonin.

TABLE I

Increase of DOPAC, but not 5-HIAA, in the superior cervical ganglion after treatment with probenecid

\begin{tabular}{lccc}
\hline \multicolumn{1}{c}{ Treatment } & Serotonin & 5-HIAA & DOPAC \\
Saline & \multicolumn{1}{c}{ pmol/mg protein \pm SEM } & \\
Probenecid," $30 \mathrm{~min}$ & $16 \pm 1$ & $22 \pm 3$ & $29 \pm 3$ \\
Probenecid, $60 \mathrm{~min}$ & $16 \pm 2$ & $22 \pm 2$ & $67 \pm 6^{\prime \prime}$ \\
\hline
\end{tabular}

"Dose, $400 \mathrm{mg} / \mathrm{kg}$, i.p.; killed after 30 or $60 \mathrm{~min} . N=7$ to 10 .

" $p<0.001$ when compared with saline-treated rats.

"The sensitivity of the detection and recording system was adjusted to provide a convenient measure of serotonin and 5-HIAA content in the ganglion. However, at the sensitivity required, the large druginduced increase of DOP $A \mathrm{C}$ exceeded the capacity of the recording equipment; thus, DOPAC could not be measured accurately.
TABLE II

The influence of cholinergic drugs on the content of serotonin in the superior cervical ganglion

\begin{tabular}{lc}
\hline \multicolumn{1}{c}{ Treatment } & Serotonin \\
\hline & pmol/mg protein $\pm S E M$ \\
Saline & $17 \pm 2$ \\
Carbachol, $1 \mathrm{mg} / \mathrm{kg}$, s.c. & $22 \pm 1^{\prime \prime}$ \\
Nicotine, $10 \mathrm{mg} / \mathrm{kg}$, s.c. & $17 \pm 2$ \\
Hexamethonium, $7 \mathrm{mg} / \mathrm{kg}$, i.p. & $16 \pm 3$ \\
Oxotremorine, $0.2 \mathrm{mg} / \mathrm{kg}$, s.c. & $29 \pm 2$ \\
Atropine, $20 \mathrm{mg} / \mathrm{kg}$, i.p. & $12 \pm 1^{\prime \prime}$ \\
Atropine + oxotremorine & $11 \pm 1^{\prime \prime}$
\end{tabular}

"All rats were killed after $15 \mathrm{~min} . N=5$ to 9 .

${ }^{b} p<0.05$ when compared with saline treatment.

$p<0.001$ when compared with saline treatment.

TABLE III

The consequences of unilateral decentralization and oxotremorine treatment on superior cervical ganglion serotonin

Rats were decentralized unilaterally 10 days before treatment with oxotremorine $(0.2 \mathrm{mg} / \mathrm{kg}$, s.c.). $N=6$ to 10 .

\begin{tabular}{lc}
\hline & Serotonin \\
\hline & pmol/mg protein $\pm S E M$ \\
Surgery & $16 \pm 1$ \\
None & $7 \pm 1 "$ \\
Decentralized & $21 \pm 2 "$ \\
Sharl & \\
& \\
Treatment & $29 \pm 2 "$ \\
None-oxotremorine & $22 \pm 1 "$ \\
Decentralized-oxotremorine & $64 \pm 3 "$ \\
Sham-oxotremorine & \\
\hline " $p<0.05$ when compared with no surgery. \\
" $p<0.01$ when compared with corresponding animals not treated \\
with oxotremorine.
\end{tabular}

Oxotremorine was administered to rats 10 days after unilateral decentralization (Table III) to test whether the rise of serotonin in the ganglion after the administration of muscarinic agonists was of local rather than central origin. Following decentralization, the content of serotonin fell in the ganglion, while in the opposite ganglion (sham), the content rose. The results were the same whether they were based on serotonin per mg of protein or serotonin per ganglion. Treatment with oxotremorine resulted in an increase of serotonin in both decentralized and sham surgery ganglia by about $300 \%$, providing evidence that the rise was a consequence of oxotremorine acting locally at the ganglion. The surgically treated animals were more sensitive to oxotremorine treatment than the control animals.

The rate of serotonin formation was evaluated by administering pargyline $(75 \mathrm{mg} / \mathrm{kg}$, i.p.) and following the serotonin increased in the ganglion (Fig. 1) with time. Pargyline, at a dose of $75 \mathrm{mg} / \mathrm{kg}$ (i.p.), results in a rapid inhibition of ganglionic monoamine oxidase (Karoum et al., 1977). Serotonin accumulated in the ganglion at a rate of $112 \mathrm{pmol} / \mathrm{mg}$ of protein/hr. Serotonin formation also was estimated from the rise of 5-HTP after blocking amino acid decarboxylase by treatment with benserazide (700 mg/kg, i.p.) and was found to be $60 \mathrm{pmol} / \mathrm{mg}$ of protein/hr (data not shown). To evaluate whether the 
rise of serotonin in the ganglion after oxotremorine treatment was the result of increased formation, pargyline was administered together with oxotremorine $(0.2 \mathrm{mg} /$ $\mathrm{kg}$, s.c.), and the content of serotonin was followed with time (Fig. 1). The rate of increase of serotonin was about twice as fast, $236 \mathrm{pmol} / \mathrm{mg}$ of protein $/ \mathrm{hr}$, as the rise in control animals.

Several drugs that alter the content of serotonin and 5 -HIA $\Lambda$ in the brain were active in the ganglion (Table IV). $p$-Chlorophenylalanine, fluoxetine, and reserpine all lowered ganglionic serotonin. $p$-Chlorophenylalanine and fluoxetine also lowered the content of 5-HIAA.

An analysis of rat plasma for serotonin and 5-HIAA (Table $\mathrm{V}$ ) revealed that both are significantly lower in plasma than in ganglia. A ganglion weighs about $1 \mathrm{mg}$ and contains about $2 \mathrm{pmol}$ of serotonin and 5-HIAA. In contrast, the plasma contains less than $10 \%$ of the quantities found in the ganglion.

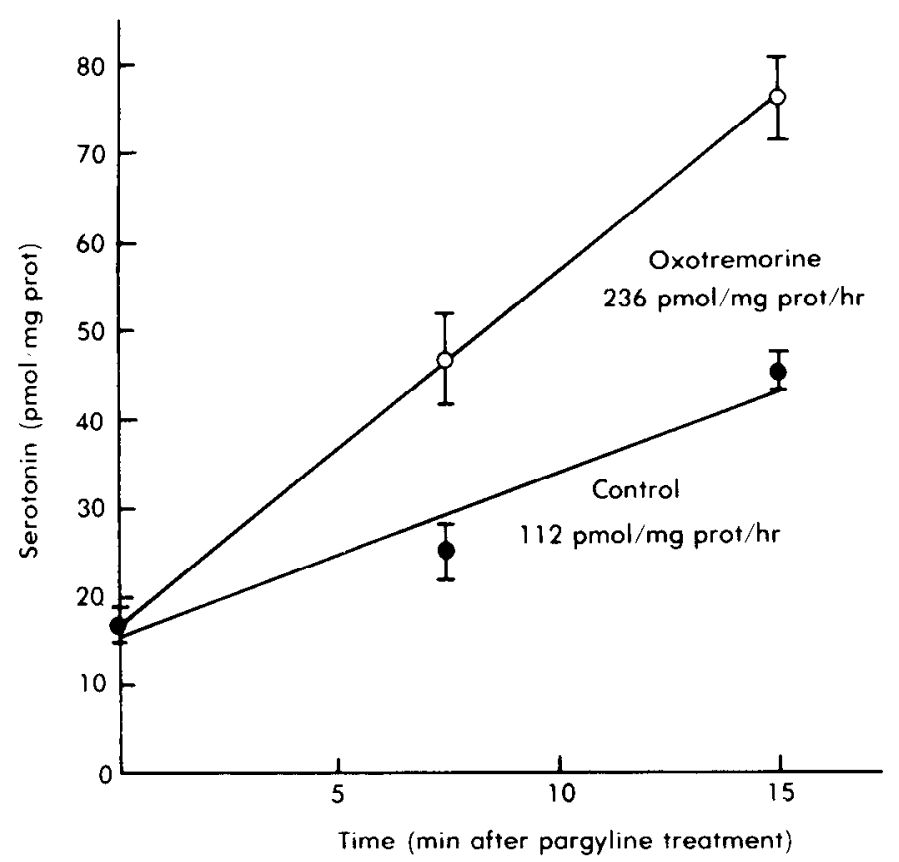

Figure 1. Estimation of the rate of formation of serotonin in the superior cervical ganglion of control and oxotremorinetreated rats. Pargyline ( $75 \mathrm{mg} / \mathrm{kg}$, i.p.) was administered alone or $1 \mathrm{~min}$ after administering oxotremorine $(0.2 \mathrm{mg} / \mathrm{kg}, \mathrm{s.c}$.). The data are reported as the mean \pm SEM for five to seven samples. Slopes were calculated by least squares analysis.

TABLE IV

Response of the rat superior cervical ganglion to drugs that alter the serotonin content of the brain

\begin{tabular}{lcc}
\hline \multicolumn{1}{c}{ "'reatment" } & Serotonin & 5-HIAA \\
\hline & pmol/mg protein \pm SEM \\
Saline & $17 \pm 1$ & $22 \pm 2$ \\
p-Chlorophenylalanine, $300 \mathrm{mg} /$ & $9 \pm 1^{b}$ & $15 \pm 2^{b}$ \\
$\quad$ kg, i.p. & & \\
Fluoxetine, $10 \mathrm{mg} / \mathrm{kg}$, i.p. & $12 \pm 1^{b}$ & $16 \pm 2^{b}$ \\
Reserpine, $5 \mathrm{mg} / \mathrm{kg}$, i.p. & $10 \pm 1^{b}$ & $18 \pm 2$ \\
\hline
\end{tabular}

" $p$-Chlorophenylalanine was administered in two injections given 12 hr apart; the rats were killed $12 \mathrm{hr}$ after the last dose. The rats given fluoxetine were killed $30 \mathrm{~min}$ after the injection and those given reserpine were killed $6 \mathrm{hr}$ after the injection. $N=5$ to 7 .

" $p<0.05$ when compared with saline treatment.
TABLE V

Content of serotonin and 5-HIAA in the plasma of the rat

Rats were anesthetized with chloral hydrate $(400 \mathrm{mg} / \mathrm{kg}$, i.p.), and blood was withdrawn from the abdominal aorta into a plastic syringe containing $1 \mathrm{ml}$ of a $4 \%$ solution of sodium citrate. The blood was centrifuged at $3,000 \times g$ for $10 \mathrm{~min}$. The clear supernatant was removed and centrifuged at $8,000 \times g$ for $15 \mathrm{~min}$. The supernatant resulting from the second centrifugation was assayed for serotonin and 5-HIAA as described under "Materials and Methods." The calculation is based on a $50 \%$ packed red blood cell volume.

\begin{tabular}{lc}
\hline Indole & Plasma \\
\hline & $p m o l / \mu l \pm S E M$ \\
Serotonin & $0.084 \pm 0.006$ \\
5-HIAA & $0.15 \pm 0.04$ \\
\hline
\end{tabular}

\section{Discussion}

There is now experimental evidence for the presence of a serotonin-containing neuronal cell system in rat sympathetic ganglia. Although some serotonin is probably present in mast cells of the ganglion, the majority of the serotonin-containing cells have been characterized by Verhofstad et al. (1981) as a separate and distinct group of SIF cells. These serotonin-containing SIF cells have many of the characteristics of serotonergic neurons of the brain. For example, we have found that both the serotonin and 5-HIAA content in the ganglia decrease after treatment with the tryptophan hydroxylase inhibitor $p$-chlorophenylalanine just as in the brain (Koe and Weissman, 1966). In addition, reserpine, which depletes serotonin from neurons in the brain (Brodie et al., 1966), reduces the serotonin content in the ganglia. Treatment with fluoxetine, a serotonin reuptake blocker, caused a significant fall in the 5-HIAA content in the ganglia, which is consistent with reports from experiments using the brain (Fuller and Wong, 1977). However, fluoxetine has no effect on brain serotonin content (Fuller and Wong, 1977; data not shown), but it does reduce the serotonin content in the ganglia. Presumably, if reuptake plays a major role in maintaining the serotonin content of the SIF cells, blocking reuptake should lower serotonin content in the ganglia.

Both DOPAC and 5-HIAA, the acidic metabolites of dopamine and serotonin, are eliminated from the brain by a probenecid-sensitive acid transport system (RofflerTarlov et al., 1971; Neff et al., 1967). Our finding that probenecid increased the content of DOPAC, but not 5HIAA, in the ganglia suggests that this is not the case in this tissue. Rather, it appears that 5-HIAA is eliminated from the ganglia by processes other than an acid transport system. Since serotonin-containing SIF cells are associated with blood vessels in the superior cervical ganglion, it is possible that 5-HIAA could be lost from the ganglion into the circulation.

Dopamine-containing SIF cells are modulated by preganglionic cholinergic nerves that end on muscarinic receptors (Libet and Owman, 1974; Karoum et al., 1977). Our findings indicate that serotonin-containing SIF cells are under a similar control mechanism. Muscarinic agonists increase the content of serotonin in the ganglion. This increase of serotonin after muscarinic agonists is probably the consequence of increased serotonin formation, as its rate of accumulation doubles when the rats are treated with oxotremorine prior to pargyline treatment. The increase in serotonin content produced by 
oxotremorine was blocked by atropine; in addition, atropine treatment alone lowered the content of serotonin. The lower content after atropine treatment suggests that serotonin-containing SIF cells are activated tonically by preganglionic cholinergic nerves. Moreover, unilateral decentralization of the ganglion results in an increase of serotonin in the innervated ganglion and a decrease in the decentralized ganglion. This observation is consistent with the hypothesis that serotonin-containing SIF cells are under the influence of preganglionic cholinergic activity and also suggests that the loss of function in the denervated ganglion may be compensated by a rise of serotonin in the intact ganglion.

The calculated rate of serotonin formation in the ganglion (112 pmol $/ \mathrm{mg}$ of protein $/ \mathrm{hr}$ ), as measured by its accumulation after the blockade of monoamine oxidase, is significantly faster than reported for the rat caudate nucleus (16 pmol $/ \mathrm{mg}$ of protein $/ \mathrm{hr}$ ) or hippocampus (15 $\mathrm{pmol} / \mathrm{mg}$ of protein $/ \mathrm{hr}$ ) and approaches the rate found for the median raphe nucleus (153 pmol/mg of protein/ hr) (Neckers and Meek, 1976). The rapid rate of serotonin formation in the ganglion may be an indication that it plays an important role in ganglionic transmission. Indeed, serotonergic drugs that act at peripheral sites to lower blood pressure may be acting in part, at serotonin receptors in the ganglion (DeCree et al., 1981).

The functional role of serotonin for ganglionic transmission is unknown. Serotonin has been reported to have both excitatory and inhibitory effects on ganglionic transmission. Several recent reports have provided evidence that serotonin may inhibit the release of acetylcholine from preganglionic neurons (North et al., 1980; Dun and Karczmar, 1981). Serotonin also has effects on postganglionic neurons; however, fewer than one-third of the neurons respond to serotonin. Thus, Dun and Karczmar (1981) have postulated that postganglionic neurons are not the primary site of action for serotonin. These reports suggest separate roles for dopamine- and serotonin-containing SIF cells in the local circuits for modulating ganglionic transmission. Apparently, both SIF cell systems receive information from preganglionic cholinergic neurons via muscarinic receptors. However, dopaminecontaining SIF cells generally are considered to act postsynaptically to modulate the responsiveness of the sympathetic neurons to acetylcholine (Libet and Tosaka, 1970), while serontonin-containing SIF cells may act presynaptically to modulate the quantity of acetylcholine released from preganglionic neurons (North et al., 1980; Dun and Karczmar, 1981).

In summary, we have provided experimental evidence that the serotonin-containing SIF cells of the rat superior cervical ganglion are responsive to muscarinic agonists. Moreover, we have identified some of the pharmacological characteristics of these neurons. A hypothetical model is suggested for local circuit control of ganglionic transmission by dopamine- and serotonin-containing SIF cells. The model may be of value for future studies of the ganglia and for explaining some of the peripheral pharmacological responses observed for serotonergic drugs.

\section{References}

Brodie, B. B., M. S. Comer, E. Costa, and A. Dlabac (1966) The role of brain serotonin in the mechanism of the central action of reserpine. J. Pharmacol. Exp. Ther. 152: 340-349.

DeCree, J., J. Leempoels, W. DeCock, H. Geukens, and H. Verhaegen (1981) The antihypertensive effects of a pure and selective serotonin-receptor blocking agent ( $R$ 41468) in elderly patients. Angiology 32: 137.

Dun, N. J., and A. G. Karczmar (1981) Evidence for a presynaptic inhibitory action of 5-hydroxytryptamine in mammalian sympathetic ganglion. J. Pharmacol. Exp. Ther. 217: 714718.

Fuller, R. W., and D. T. Wong (1977) Inhibition of serotonin reuptake. Fed. Proc. 36: 2154-2156.

Hertzler, E. C. (1961) 5-Hydroxytryptamine and transmission in sympathetic ganglia. Br. J. Pharmacol. 17: 406-413.

Karoum, F., C. K. Garrison, N. H. Neff, and R. J. Wyatt (1977) Trans-synaptic modulation of dopamine metabolism in the rat superior cervical ganglion. J. Pharmacol. Exp. Ther. 201: 654-661.

Koe, B. K., and A. Weissman (1966) p-Chlorophenylalanine: Specific depletion of brain serotonin. J. Pharmacol. Exp. Ther. 154: 499-516.

Lackovic, Z., M. Parenti, and N. H. Neff (1981) Simultaneous determination of femtomole quantities of 5-hydroxytryptophan, serotonin and 5-hydroxyindoleacetic acid in brain using HPLC with electrochemical detection. Eur. J. Pharmacol. 69: 347-352.

Libet, B., and C. Owman (1974) Concomitant changes in formaldehyde-induced fluorescence of dopamine interneurons and in slow inhibitory post-synaptic potentials of the rabbit superior cervical ganglion, induced by stimulation of the preganglionic nerve or by a muscarinic agent. J. Physiol. (Lond.) 237: $635-662$.

Libet, B., and T. Tosaka (1970) Dopamine as a synaptic transmitter and modulator in sympathetic ganglia. A different mode of synaptic action. Proc. Natl. Acad. Sci. U. S. A. 67: 667-673.

Liuzzi, A., F. H. Foppen, J. M. Saavedra, R. Levi-Montalcini, and I. J. Kopin (1977) Gas chromatographic-mass spectrometric assay of serotonin in rat superior cervical ganglia. Effects of nerve growth factor and 6-hydroxydopamine. Brain Res. 133: 354-357.

Lowry, O. H., N. J. Rosebrough, A. L. Farr, and R. J. Randall (1951) Protein measurement with Folin phenol reagent. J. Biol. Chem. 193: 265-275.

Neckers, L. M., and J. L. Meek (1976) Measurement of 5HT turnover rate in discrete nuclei of rat brain. Life Sci. 19: 15791584.

Neff, N. H., T. N. Tozer, and B. B. Brodie (1967) Application of steady-state kinetics to studies of the transfer of 5-hydroxyindoleacetic acid from brain to plasma. J. Pharmacol. Exp. Ther. 158: 214-218.

North, R. A., G. Henderson, Y. Katayama, and S. M. Johnson (1980) Electrophysiological evidence for presynaptic inhibition of acetylcholine release by 5 -hydroxytryptamine in the enteric nervous system. Neuroscience 5: 581-586.

Roffler-Tarlov, S., D. F. Sharman, and P. Tetgerdine (1971) 3,4-Dihydroxyphenylacetic acid and 4-hydroxy-3-methoxyphenylacetic acid in the mouse striatum: A reflection of intraand extra-neuronal metabolism of dopamine? Br. J. Pharmacol. 42: 343-351.

Verhofstad, A. A. J., H. W. M. Steinbusch, B. Penke, J. Varga, and H. W. J. Joosten (1981) Serotonin-immunoreactive cells in the superior cervical ganglion of the rat. Evidence for the existence of separate serotonin- and catecholamine-containing small ganglionic cells. Brain Res. 212: 39-49.

Wallis, D. I., and B. Woodward (1974) The facilitatory actions of 5-hydroxytryptamine and bradykinin in the superior cervical ganglion of the rabbit. Br. J. Pharmacol. 51: 521-531. 